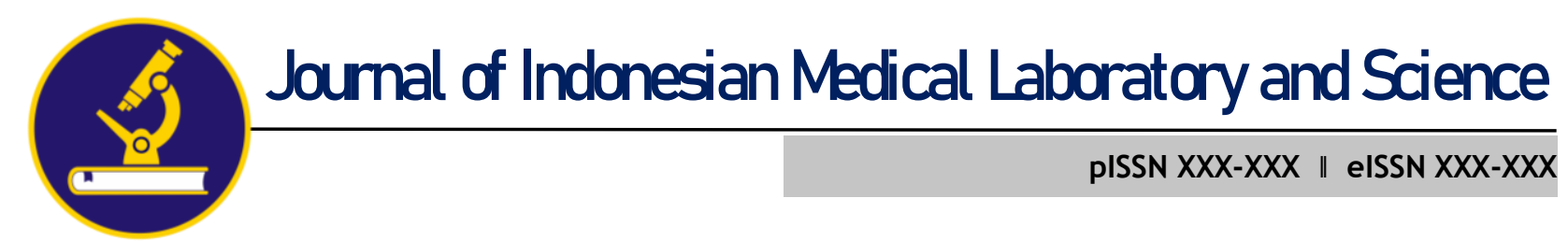

\title{
PENGARUH HEMOLISIS DALAM SERUM TERHADAP AKTIVITAS ENZIM ASPARTAT AMINOTRANSFERASE DENGAN METODE KINETIK-IFCC
}

\author{
Hilda Dila Wanti ${ }^{1} \cdot$ Fitri Fadhilah $^{1^{*}} \cdot$ Opik Taufiqurrohman $^{1}$ \\ ${ }^{1}$ Prodi D-III Analis Kesehatan, Sekolah Tinggi Analis Bakti Asih, Jawa Barat, Indonesia \\ e-Mail : fitrifadhilahssimkes@gmail.com
}

\begin{abstract}
The aspartate aminotransferase (AST) enzyme is a mitochondrial enzyme that functions to catalyze the alternating transfer of amino groups from aspartic acid to a-oxaloacetic acid to form glutamic acid and oxaloacetic acid. AST is present in erythrocytes so that if hemolysis occurs, the erythrocytes rupture will cause an increase in the activity of the AST enzyme that comes out of erythrocytes. This study aims to determine the effect of hemolysis in serum on the examination of AST enzyme activity. This research method is experimental by comparing normal serum with serum hemolysis. The research sample involved 16 students who would be examined for AST enzyme activity. The results showed that the activity of AST enzymes in normal serum had an average of $24.63 \mathrm{IU} / \mathrm{L}$ whereas in serum hemolysis there was an average of $39.38 \mathrm{IU} / \mathrm{L}$. The results of the data showed that there was an increase in AST enzyme activity in serum hemolysis compared to normal serum. The data were then analyzed using the $T$ test, and the Sig. 0.001 where $p<0.05$ proved that AST enzyme activity in normal serum and serum hemolysis was stated to be significantly different.
\end{abstract}

Keywords : Hemolysis, Enzyme, Aspartate Aminotransferase

\begin{abstract}
Abstrak
Enzim aspartat aminotransferase (AST) merupakan enzim mitokondria yang berfungsi mengkatalisis pemindahan bolak-balik gugus amino dari asam aspartat ke asam a-oksaloasetat membentuk asam glutamat dan oksaloasetat. AST terdapat di dalam eritrosit sehingga apabila terjadi hemolisis eritrosit pecah akan menyebabkan terjadinya peningkatan aktivitas enzim AST yang keluar dari eritrosit. Penelitian ini bertujuan mengetahui pengaruh hemolisis dalam serum terhadap pemeriksaan aktivitas enzim AST. Metode penelitian ini bersifat eksperimen dengan membandingkan serum normal dengan serum hemolisis. Sampel penelitian melibatkan 16 mahasiswai yang akan dilakukan pemeriksaan aktivitas enzim AST. Hasil penelitian didapatkan aktivitas enzim AST pada serum normal memeiliki rata-rata 24,63 IU/L sedangkan pada serum hemolisis didapatkan rata-rata 39,38 IU/L hasil data menunjukan bahwa terjadi peningkatan aktivitas enzim AST pada serum hemolisis yang dibandingkan dengan serum normal. Data kemudian dianalisis dengan menggunakan uji T, dan didapatkan nilai Sig. 0,001 dimana $p<0,05$ ini membuktikan bahwa aktivitas enzim AST pada serum normal dan serum hemolisis dinyatakan berbeda signifikan.
\end{abstract}

Kata Kunci : Hemolisis, Enzim, Aspatrat Aminotrasferase

JolMedLabS. 2020;1(1):48-56

jurnal.aiptlmi-iasmlt.id | 48 


\section{PENDAHULUAN}

Pelayanan laboratorium kesehatan atau klinik adalah pelayanan yang dapat menunjang diagnosis penyakit atau monitoring kesembuhan pasien. Di laboratorium, kesalahan dalam pelayanan dapat dikategorikan menjadi tiga, yaitu kesalahan pada proses pra-analitik dengan persentase kesalahan sebesar 60-70\%, analitik dengan persentase kesalahan sebesar $10-15 \%$ dan pasca-analitik dengan persentase kesalahan sebesar 15-18\%. Pada kesalahan pra-analitik biasanya terjadi pada saat identifikasi sampel, kesalahan pemisahan sampel, kesalahan dalam teknik plebotomi, dan kesalahan pada alat dan bahan. Praanalitik menyumbang paling banyak dalam faktor kesalahan di laboratorium diagnostik (Fadhilah, Sari, \& Aprilianti, 2019).

Faktor pra-analitik di laboratorium yang perlu diperhatikan antara lain pengambilan spesimen darah dan persiapan reagen serta alat yang digunakan. Pengambilan spesimen harus memperhatikan kemungkinan terjadinya hemolisis. Darah diambil dan ditampung pada tabung tanpa antikoagulan (plain) kemudian dilakukan pemusingan untuk mendapatkan serum. Hemolisis perlu dihindari karena dapat mempengaruhi temuan laboratorium (Fadhilah, Riyani, \& Nopiani, 2019).

Hemolisis adalah pecahnya sel membran eritrosit, sehingga hemoglobin bebas ke dalam medium sekelilingnya (serum). Menurut Kahar (2017) kerusakan membran sel eritrosit dapat disebabkan karena mengeluarkan darah dari spuit tanpa melepas jarum terlebih dahulu sehingga akan menyebabkan sel eritrosit pecah. Apabila sel eitrosit pecah maka akan menyebabkan isi sel keluar, misalnya : enzim, elektrolit, hemoglobin sehingga tampak merah muda sampai merah pada serum. Enzim yang keluar pada saat eritrosit pecah salah satunya adalah Enzim aspartat aminotransferase (Farrell \& Carter, 2016; Kahar, 2017).

Enzim aspartat aminotransferase (AST) disebut juga glutamat oksaloasetat transminase (SGOT) merupakan enzim mitokondria yang berfungsi mengkatalisis pemindahan bolak-balik gugus amino dari asam aspartat ke asam a-oksaloasetat 
membentuk asam glutamat dan oksaloasetat (Agrawal, Dhiman, \& Limdi, 2016). AST sel darah merah ( eritrosit ) apabila terjadi hemolisis, eritrosit akan pecah dan akan menyebabkan terjadinya peningkatan aktivitas enzim AST yang keluar dari sel darah merah (Farrell \& Carter, 2016; L’Acqua \& Hod, 2015)

Berdasarkan latar belakang tersebut, peneliti tertarik untuk melakukan penelitian tentang " Pengaruh Hemolisis Dalam Serum Terhadap Aktivitas Enzim Aspartat Aminotransferase Dengan Metode Kinetik-IFCC ”.

\section{BAHAN DAN METODE}

Jenis Penelitian

Jenis penelitian ini merupakan rancangan Eksperimen. Penelitian Eksperimen adalah kegiatan percobaan yang bertujuan untuk mengetahui suatu gejala atau pengaruh yang timbul sebagai akibat dari adanya perlakuan tertentu. Pada penelitian ini digunakan sampel serum normal dan serum yang dibuat menjadi serum hemolisis.

\section{Desain Penelitian}

Desain Penelitian yang digunakan dalam penelitian ini adalah static group comparison. Dalam rancangan ini terdapat dua kelompok yang dipilih. Kelompok pertama tidak diberi perlakuan (kelompok control) dan kelompok kedua diberi perlakuan (kelompok eksperimen) dan akan diuji dengan statistik uji T.

\section{Objek dan Sampel}

Objek pada penelitian ini adalah pada mahasiswai di Sekolah Tinggi Analis Bakti Asih Bandung. Sampel adalah serum normal dan serum yang dibuat hemolisis yang diambil dari 16 mahasiswa.

\section{Lokasi dan Waktu}

Penelitian dilakukan Laboratorium Penelitian Sekolah Tinggi Analis Bakti Asih Bandung pada bulan Juni 2019. 


\section{Metode Analisis}

Kinetik-IFCC (Internasional Federation of Clinical Chemistry). Pengukuran Kinetik-IFCC adalah pengukuran fotometris dari perubahaan absorban per satuan waktu yang telah diakui oleh kimia klinik secara internasional. Pengukuran kinetik dilakukan untuk penentuan aktifitas enzim, yaitu kecepatan enzim untuk merubah subsrat (Aleya \& Berawi, 2014; Kendran, Arjana, Pradnyantari, \& et al, 2017).

Alat

Alat-alat yang digunakan dalam penelitian ini antara lain : Clinipette 100 mikron dan 1000 mikron, fotometer, rak tabung, tabung serologi, tip (kuning dan biru) dan tissue

\section{Bahan}

Bahan-bahan yang digunakan dalam penelitian ini antara lain : Sampel serum, reagen AST

\section{Prosedur Kerja}

\section{Pengambilan Darah Vena}

Digunakan sarung tangan dan jas laboratorum yang rapih dan bersih lalu disiapkan peralatan yang akan digunakan untuk pengambilan darah vena kemudian dipasang tourniquet pada lengan bagian atas setelah posisi vena ditemukan dan meminta pasien untuk mengepal tanggannya kemudian dibersihkan permukaan pembuluh vena yang akan ditusuk dengan kapas alkohol 70\% dengan gerakan memutar dari dalam keluar dan membiarkannya mongering kemudian tourniquet dilongggarkan dan dilakukan pengambilan darah sebanyak $3 \mathrm{ml}$. Lalu dicabut jarumnya dan ditutup luka bekas tusukan dengan kapas kering selanjutnya darah dimasukan kedalam tabung yang telah disediakan dan diberi nama dan nomor.

\section{Pembuatan serum normal}

Dimasukan $1 \mathrm{ml}$ darah kedalam tabung dengan melepas jarum, kemudian disisakan $2 \mathrm{ml}$ darah untuk membuat serum hemolisis kemudian darah yang telah dimasukan kedalam tabung dibiarkan mengendap selama 30 menit 
selanjutnya dilakukan senrifuge terhadap darah dengan kecepatan $3000 \mathrm{rpm}$ selama 10 menit dan segera pisahkan serum dari endapannya.

\section{Pembuatan serum hemolisis}

Didiamkan $2 \mathrm{ml}$ darah di dalam spuit selama 15 menit kemudian darah dikeluarkan dari spuit tersebut lewat ujung spuit tanpa melepas jarum lalu darah dibiarkan mengendap selama 30 menit selanjutnya dilakukan senrifuge terhadap darah dengan kecepatan 3000 rpm selama 10 menit dan segera pisahkan serum dari endapannya (Kahar, 2017).

\section{Pemeriksaan Aktivitas Enzim AST}

Dibawa reagen ke suhu kamar $\left(15-30^{\circ} \mathrm{C}\right)$ lalu diatur fotometer ke-0 (nol) dengan aquabiset kemudian dipipet serum kedalam tabung sebanyak $100 \mu \mathrm{l}$ lalu ditambahkan larutan kerja (reagen) sebanyak $1000 \mu \mathrm{L}$ lalu dicampur dan diinkubasi pada suhu $37^{\circ} \mathrm{C}$ Setelah 60 detik dibaca dan dicatat absorban kemudian diulangi pembacaan absorban tepat setelah 1,2 dan 3 menit selanjutnya dihitung perbedaan absorbansi rata-rata permenit, kemudian dikalikan dengan faktor 1746 dan akan menghasilkan hasil dalam IU/L.

\section{HASIL}

Sampel yang digunakan pada penelitian ini adalah serum normal dan serum hemolisis yang akan dilakukan pengujian pemeriksaan aktivitas enzim AST.

Tabel 3.1. Hasil Pemeriksaan Aktivitas Enzim AST Pada Serum Normal Dan Serum Hemolisis

\begin{tabular}{cccc}
\hline \multicolumn{4}{c}{ Aktivitas Enzim AST ( IU/L ) } \\
\hline Pengulangan & $\begin{array}{c}\text { Serum } \\
\text { Normal }\end{array}$ & $\begin{array}{c}\text { Serum } \\
\text { Hemolisis }\end{array}$ & $\begin{array}{c}\% \\
\text { Kenaikan }\end{array}$ \\
\hline $\mathbf{1}$ & 26 & 41 & $58 \%$ \\
\hline $\mathbf{2}$ & 25 & 39 & $56 \%$ \\
\hline 3 & 27 & 42 & $56 \%$ \\
\hline 4 & 24 & 39 & $63 \%$ \\
\hline
\end{tabular}




\begin{tabular}{cccc}
\hline $\mathbf{5}$ & 18 & 34 & $89 \%$ \\
\hline $\mathbf{6}$ & 21 & 36 & $71 \%$ \\
\hline $\mathbf{7}$ & 19 & 34 & $79 \%$ \\
\hline $\mathbf{8}$ & 29 & 43 & $48 \%$ \\
$\mathbf{9}$ & 29 & 44 & $52 \%$ \\
\hline 10 & 34 & 48 & $41 \%$ \\
\hline 11 & 25 & 39 & $56 \%$ \\
\hline 12 & 19 & 33 & $74 \%$ \\
\hline 13 & 21 & 36 & $71 \%$ \\
\hline 14 & 18 & 33 & $83 \%$ \\
\hline 15 & 32 & 47 & $47 \%$ \\
\hline Jumlah & 27 & 42 & $56 \%$ \\
\hline Rata-Rata & 394 & 630 & \\
\hline
\end{tabular}

Setelah dilakukan penelitian diperoleh data yang akan dilakukan pengolahan data dengan menggunakan uji statistik yaitu uji T. Dari data diatas didapatkan hasil uji $T$ nilai sig 0.001 dimana $p<0.05$ maka data dinyatakan berbeda signifikan.

\section{DISKUSI}

Penelitian ini merupakan rancangan Eksperimen. Penelitian Eksperimen adalah kegiatan percobaan yang bertujuan untuk mengetahui suatu gejala atau pengaruh yang timbul sebagai akibat dari adanya perlakuan tertentu. Pada penelitian ini digunakan sampel serum normal dan serum yang dibuat menjadi serum hemolisis.

Hemolisis adalah pecahnya membran eritrosit, sehingga hemoglobin bebas ke dalam medium sekelilingnya (serum). Menurut Farrel (2016) kerusakan membran sel eritrosit dapat disebabkan oleh mengeluarkan darah dari spuit tanpa melepas jarum terlebih dahulu, karena darah yang ada didalam spuit dipaksa keluar melalui lubang spuit yang kecil sehingga akan menyebabkan sel eritrosit pecah dan menyebabkan isi sel keluar, misalnya enzim, elektrolit dan hemoglobin sehingga tampak merah muda sampai merah pada serum. Enzim yang keluar pada saat eritrosit pecah salah satunya adalah 
Enzim aspartat aminotransferase, sehingga apabila terjadi hemolisis, eritrosit akan pecah dan akan menyebabkan terjadinya peningkatan aktivitas enzim aspartat aminotransferase yang keluar dari eritrosit.

Enzim aspartat aminotransferase (AST) disebut juga serum glutamat oksaloasetat transminase (SGOT) merupakan enzim mitokondria yang berfungsi mengkatalisis pemindahan bolak-balik gugus amino dari asam aspartat ke asam a-oksaloasetat membentuk asam glutamat dan oksaloasetat (Price, Sylvia A, \& Wilson, 2006).

Pada penelitian ini pemeriksaan enzim AST dilakukan dengan menggunakan metode Kinetik-IFCC. Metode Kinetik-IFCC adalah pengukuran fotometris dari perubahaan absorban per satuan waktu yang telah diakui oleh kimia klinik secara internasional. Pengukuran kinetik dilakukan untuk penentuan aktifitas enzim, yaitu kecepatan enzim untuk merubah substrat (Aleya \& Berawi, 2014; Kendran et al., 2017).

Setelah dilakukan uji deskriptif dapat diketahui bahwa aktivitas enzim AST pada serum normal didapatkan rata-rata 24,63 IU/L dan pada serum hemolisis didapatkan rata-rata 39,38 IU/L. Hasil data diatas menunjukan bahwa terjadi peningkatan aktivitas enzim AST pada serum hemolisis yang dibandingkan dengan serum normal.

Data yang didapatkan diuji menggunakan uji T, Uji ini menghitung selisih antara nilai dua variabel untuk tiap kasus dan menguji apakah selisih rata-rata tersebut bernilai nol. Setelah dilakukan uji T didapatkan nilai sig 0.001 dimana $\mathrm{p}<0.05$ ini membuktikan bahwa hasil pemeriksaan aktivitas enzim AST pada serum normal dan serum hemolisis dinyatakan berbeda signifikan.

Hasil pemeriksaan aktivitas enzim AST pada serum normal dan serum hemolisis ditemukan perbebaan. Secara klinis, perbedaan ini dapat dianggap bermakna karena adanya teori yang mendukung yaitu aktivitas enzim AST pada serum hemolisis dapat menyebabkan kenaikan palsu yang disebabkan oleh keluarnya enzim AST yang terdapat di dalam eritrosit, sehingga aktivitas enzim AST pada serum hemolisis secara teori lebih tinggi dibandingkan serum normal. 


\section{KESIMPULAN}

Berdasarkan hasil penelitian yang telah dilakukan maka penulis menarik kesimpulan bahwa terdapat pengaruh hemolisis dalam serum terhadap aktivitas enzim aspartat aminotransferase yang ditandai dengan peningkatan pada serum hemolisis yang dibandingkan dengan serum normal. Hasil uji T dalam penelitian didapatkan ini nilai sig 0.001 dimana $p<0.05$ yang menunjukan bahwa terdapat perbedaan yang signifikan pada hemolisis dalam serum terhadap aktivitas enzim aspartat aminotransferase dengan metode kinetik-IFCC.

\section{UCAPAN TERIMAKASIH}

Seluruh Civitas Akademika Sekolah Tinggi Analis Bakti Asih Bandung.

\section{KONFLIK KEPENTINGAN}

Tidak ada konflik kepentingan dalam penelitian ini.

\section{REFRENSI}

Agrawal, S., Dhiman, R. K., \& Limdi, J. K. (2016). Evaluation of abnormal liver function tests. Postgraduate Medical Journal. https://doi.org/10.1136/postgradmedj-2015-133715

Aleya, \& Berawi, K. N. (2014). Korelasi Pemeriksaan Laboratorium SGOT/SGPT dengan Kadar Bilirubin pada Pasien Hepatitis C. Fakultas Kedokteran, Universitas Lampung.

Fadhilah, F., Riyani, A., \& Nopiani, A. (2019). Temperature Efectivity and Storage Time in Blood Sample preparation through Volume of Serum at Fasting Glucose , Total Cholesterol and Trigliserida Testing Efektifitas Suhu Dan Lama Penyimpanan Pada Preparasi Sampel Darah Terhadap Volume Serum Pada Pemeri, 15(2).

Fadhilah, F., Sari, A. B., \& Aprilianti, A. (2019). the Effect of Test Tube Sterilization From Serum Lipemic Against Levels of Triglyceride Gpo-Pap 
Method. Indonesian Journal of Medical Laboratory Science and Technology, 1(1), 38-43. https://doi.org/10.33086/ijmlst.v1i1.878

Farrell, C. J. L., \& Carter, A. C. (2016). Serum indices: managing assay interference. Annals of Clinical Biochemistry, 53(5), 527-538. https://doi.org/10.1177/0004563216643557

Kahar, H. (2017). Pengaruh Hemolisis Terdapat Kadar Serum Glutamate Pyruvate Transaminase (SGPT) Sebagai Salah Satu Parameter Fungsi Hati. THE JOURNAL OF MUHAMMADIYAH MEDICAL LABORATORY TECHNOLOGIST. https: / / doi.org/10.30651/jmlt.v1i1.981

Kendran, A. A. S., Arjana, A. A. G., Pradnyantari, A. A. S. I., \& et al. (2017). Aktivitas Enzim Alanine-Aminotransferase dan Aspartate Aminotransferase pada Tikus Putih Jantan yang Diberi Ekstrak Buah Pinang. Buletin Veteriner Udayana. https: //doi.org/10.21531/bulvet.2017.9.2.132

L'Acqua, C., \& Hod, E. (2015). New perspectives on the thrombotic complications of haemolysis. British Journal of Haematology. https://doi.org/10.1111/bjh.13183 